\title{
Surfaces
}

\section{IMAGES OF LEGAL HUMANISM}

\section{Douglas J. Osler}

Volume 9, 2001

TROISIÈME CONGRÈS INTERNATIONAL SUR LE DISCOURS HUMANISTE. LA RÉSISTANCE HUMANISTE AU DOGMATISME AUJOURD'HUI ET À LA FIN DU MOYEN ÂGE THIRD INTERNATIONAL CONFERENCE ON HUMANISTIC DISCOURSE. HUMANISTIC RESISTANCE TO DOGMATISM TODAY AND AT THE END OF THE MIDDLE AGES

URI : https://id.erudit.org/iderudit/1065066ar

DOI : https://doi.org/10.7202/1065066ar

Aller au sommaire du numéro

\section{Éditeur(s)}

Les Presses de l’Université de Montréal

ISSN

1188-2492 (imprimé)

1200-5320 (numérique)

Découvrir la revue

Citer cet article

Osler, D. J. (2001). IMAGES OF LEGAL HUMANISM. Surfaces, 9. https://doi.org/10.7202/1065066ar

\section{Résumé de l'article}

L'humanisme légal est une expression utilisée en référence à l'étude du droit romain par les philologues du 16e siècle. S'instituant un siècle et demi plus tard que l'humanisme, l'humanisme légal est généralement compris comme en faisant partie par son intérêt pour l'interprétation des textes latins plutôt que par sa participation aux orientations axiologiques de l'humanisme. Étrangement, l'histoire du droit a pris pour acquis le travail philologique de l'humanisme légal ne voyant pas que l'humanisme légal était lui-même inscrit dans l'histoire. D'abord, il nous faut noter que lorsqu'on en jetait les bases au 16 e siècle, le travail philologique sur le droit romain était marginal si l'on compare les publications dans ce champ aux publications de jurisprudence italienne médiévale. Ensuite, l'histoire du droit tend à diminuer la présence d'interprétations dans le travail des tenants de l'humanisme légal qui, probablement plus que cela n'est généralement reconnu, adaptaient à leur temps les textes latins inventant des valeurs qui n'ont rien de commun avec les sources romaines. Par humanisme légal, on n’a jamais voulu dire les aspects légaux d'un rapport humanitaire au monde, et il n'est probablement pas nécessaire d'en étendre ainsi le sens. Même si le travail d'interprétation du droit romain a ouvert quelques fenêtres sur les valeurs humanistes, le droit romain lui-même était la codification d'une structure de pouvoir injuste.
Ce document est protégé par la loi sur le droit d'auteur. L'utilisation des services d'Érudit (y compris la reproduction) est assujettie à sa politique d'utilisation que vous pouvez consulter en ligne.

https://apropos.erudit.org/fr/usagers/politique-dutilisation/ 
$\underline{\text { Surfaces }}$

\title{
IMAGES OF LEGAL HUMANISM
}

Douglas J. Osler

Surfaces vol IX 101.6 (v1.0a - 15.12.2001) - ISSN: 1188-2492

Tout texte reste la propriété de son auteur. Néanmoins, SURFACES demande d'être citée à l'occasion de toute autre publication du texte en question.

\begin{abstract}
Legal humanism is an expression generally used to refer to the study of Roman law by 16th Century philologists. Coming a century an a half after what is generally taken to be the birth of humanism, it is generally understood to be part of humanism mostly in its interest for the historical interpretation of Latin texts rather than for participating in the value orientation of humanism. Strangely enough, legal history has taken the philological work of legal humanism for granted not seeing that legal humanism was itself inscribed in history. First, we should note that when it was being developed in the 16th Century, this philological work in Roman law was marginal if one compares publications in that field to publications of medieval Italian jurisprudence. Secondly, legal history has tended to diminish the presence of interpretation in the work of legal humanists who probably more than is generally acknowledged adapted to their times the Latin texts inventing values which have nothing to do with the Roman sources. Legal humanism has never been used to mean the legal aspects of humanitarianism and probably needn't to be. If the work of interpretation of Roman law has opened some windows into humanistic values, Roman law itself was the codification of an unjust power structure.
\end{abstract}




\section{RÉSUMÉ}

L'humanisme légal est une expression utilisée en référence à l'étude du droit romain par les philologues du 16 e siècle. S'instituant un siècle et demi plus tard que l'humanisme, l'humanisme légal est généralement compris comme en faisant partie par son intérêt pour l'interprétation des textes latins plutôt que par sa participation aux orientations axiologiques de l'humanisme. Étrangement, l'histoire du droit a pris pour acquis le travail philologique de l'humanisme légal ne voyant pas que l'humanisme légal était lui-même inscrit dans l'histoire. D'abord, il nous faut noter que lorsqu'on en jetait les bases au 16e siècle, le travail philologique sur le droit romain était marginal si l'on compare les publications dans ce champ aux publications de jurisprudence italienne médiévale. Ensuite, l'histoire du droit tend à diminuer la présence d'interprétations dans le travail des tenants de l'humanisme légal qui, probablement plus que cela n'est généralement reconnu, adaptaient à leur temps les textes latins inventant des valeurs qui n'ont rien de commun avec les sources romaines. Par humanisme légal, on n'a jamais voulu dire les aspects légaux d'un rapport humanitaire au monde, et il n'est probablement pas nécessaire d'en étendre ainsi le sens. Même si le travail d'interprétation du droit romain a ouvert quelques fenêtres sur les valeurs humanistes, le droit romain lui-même était la codification d'une structure de pouvoir injuste.

\section{Legal Humanism in the Renaissance and Now}

The sphere of the law inevitably intersects with that of humanism. Humanism, a recognition of the dignity of man and a concern for his moral and physical welfare, naturally turns its attention to the law, to crime and punishment. An association test for the word humane would very often result in the response: "the humane treatment of prisoners." The abolition of cruel and unusual punishments, the amelioration of prison 
conditions, an emphasis on rehabilitation rather than retribution towards the individual designated as criminal: this is the programme of the legal humanist. Humanism - the humanist conscience - common humanity - human rights - the humane treatment of prisoners: the line of connection is direct.

The lawyer is professionally integrated in the process of social control and the enforcement of norms. It is not then just a matter of private conscience, but of personal involvement in the stand against the use of torture, imprisonment without trial, the holding of political prisoners, and the whole spectrum of human rights. First and foremost, then, we would expect the legal humanist to continue the long-standing but still far from victorious struggle against the most fundamental denial of human dignity of all, namely the death penalty. This is closely followed by the concern for prison conditions that consists of massive overcrowding in antiquated buildings in most Western countries. Even when they were built in a far from humane 19th century they were intended only for a fraction of the numbers which they are now made to hold. The high prison walls now serve not only to contain their inmates but also to symbolically hide from the outside society that depends upon them to enclose the vicious world of violence, brutality, gangs, homosexuality, and drug abuse. Drug-abuse is to be understood in a double sense - both the illegal drugs circulating among prisoners to make life tolerable, and the legal drugs massively administered by the authorities in an attempt to keep the whole explosive situation under some sort of control.

And what about the perennial problem of inequalities within the legal system where class bias grants the rich access to top-flight attorneys and leaves the illiterate and inarticulate to beg in bewilderment for help from illfinanced legal welfare clinics (that have not already fallen victim to "necessary" government cutbacks)? Or what about the class bias that lies behind the popular images of crime: bank robbery? Who can cite the latest statistics for the infinitesimally insignificant losses due to the masked and armed bank robber, in comparison with the enormous "deficits" occasioned by the frauds perpetrated by the gentlemen in suits who sit in the glistening offices high above the customer floor?

How do you combat endemic police brutality and racial bias, or its social origin? What offended the humanist sensibilities more in the Rodney King case - the brutal beating by police officers, or the depths of racial prejudice that led a jury to bring in a verdict of not guilty 
when incontrovertible evidence was presented on film before their very eyes? (In light of this case is there any point in even raising the question of whether the battered and broken body, which appears patched up in court the morning after arrest has been systematically beaten in a prison cell or has sustained injuries due to "a minimum application of force while resisting arrest"?)

These are perhaps some of the themes that spring to mind as concerns of the modern humanist when he turns his attention to matters of law, criminology and human rights. Was there legal humanism in the Renaissance? Can we trace the first stirrings of such concerns in the law of the Renaissance, the age that discovered the individual and placed man at the centre of the universe, in which legal humanism was born?

The subject of the conference is "The humanistic resistance to dogma at the end of the Middle Ages..." For a student of legal humanism the subject matter, and above all the period of history is evident. Clearly we are in the 15th and early 16 th centuries. Who were the humanists? The humanists were the scholars of antiquity, active in the 14th-16th centuries. Yet something is not quite right here. For the title continues with two very significant words: "and now" - humanistic resistance to dogma now, in the contemporary world. The word humanistic has changed meaning. It does not, then, refer to the small group of classical scholars in the Renaissance, who idolized Antiquity and attacked medieval scholasticism. Humanism is now being used to describe a contemporary, not a long-gone, historical phenomenon. This illustrates what is perhaps an irresistible tendency to seek the historical roots of what we call humanism or the humanities in the Renaissance. Where else, indeed, should we look for these roots if not in what is proclaimed to be the age of humanism, the rebirth of the studia humanitatis?

If I am skeptical about this blurring of the term humanism and the humanities, this arises out of the nature of my personal research - specialization in legal humanism. The outline of the concerns of the legal humanist that I have given above is nothing but the purest invention. More exactly, it involves a re-definition of the term in a completely novel usage. For amongst legal historians no one has ever applied the term legal humanism to the legal aspects of humanitarianism. More to the point, no one has ever dreamed of seeking the origins of this movement in the utterly, utterly remote legal world of the Renaissance. There was legal 
humanism in the Renaissance, but there was - for sure no humanity in this humanism.

\section{Law in the Renaissance}

Let us consider the method of gathering evidence in a criminal trial in the age of the flowering of legal humanism, the 16th or by extension the 16th to 18th centuries. First the prosecutor's assistant would lay his instruments before the eyes of the accused; the squeamish could be counted upon to confess already at this point. Should the accused obstinately still maintain his or her innocence, the interrogator would move on to the next stage. The accused would be stripped and the thumbscrews or leg box put into position. This stage ought not to be hurried, for the demoralization and terror it engendered might often be sufficient to preclude the need for the actual application of pain. Should the stubbornness of the accused still not have been overcome, it was necessary for stronger measures. The thumbscrews would now be tightened and the thumbs of the accused agonizingly pressed between two pieces of iron; the device for the legs worked on the same principle. The pain threshold could be heightened at any time by hitting these devices with a hammer. A more severe degree of torture could be obtained by suspension; the feet would be tied to the hands, held backwards over the head, while the accused was hoisted until the arms were wrenched from their sockets. Again hanging weights on the accused's legs could increase the agony. The most severe form of interrogation, however, was whipping, the application of red-hot brands, and the hammering of wood splinters under the fingernails. The variations were, of course, endless, and after the confession was duly forthcoming the court could proceed to sentence.

Prime place among the range of choices for sentencing was, of course, occupied by the death penalty - hanging, decapitation, burning, drowning; more rarely burying alive or drawing and quartering. This was appropriate for a wide range of serious crimes, among which Damhouder, the leading criminal jurist of the 16th century, names an act of oral sex between male and female (since this was defined by law as an act of sodomy, an unspeakable crime for which the death penalty was, of course, prescribed). The alternative to the death penalty was corporal punishment, punishment 
affecting the body. In the 16th century blinding and mutilation (amputation of ear, nose, tongue, hand) were still common (the arm would be placed on a block, the hand chopped off with an axe, and then hung up in a prominent place pour encourager les autres); but whipping, in various degrees of duration and severity, was the most popular. Such punishments were often accompanied by banishment from the community, but this too might be equivalent to a sentence of death.

\section{The model humanist}

Let us be absolutely clear about one thing. It never even entered the mind of any legal humanist of the Renaissance that there was anything remotely undesirable about the above regime of criminal investigation and punishment. The suppression of crime was not really the concern of the legal humanists, nor did they express any murmurs of doubt in passing while on their busy way about other legal pursuits. If we want an image of the humanist view on these matters, we could do worse than keep the figure of Martinus Antonius Delrio before our eyes. Active in the Southern Netherlands in the second half of the 16th century, Delrio can be taken to typify the classical, Christian and legal humanist. On the classical front, he edited and annotated the Roman poets Ennius and Claudian, the tragedian Seneca, and the topographer Solinus. In Biblical studies he wrote a commentary and catena mystica on the Song of Songs and on Jeremiah, compiled a collection of sacred adages from the Old and New Testament, and also wrote Florida Mariana, a series of panegyrics in praise of the most sacred Mary Mother of God. Of his legal works one is an index to the leading humanist juristic commentaries on specific texts of Roman law, still useful, incidentally, for finding one's way around their writings. The perfect model of the humanist scholar, the master of nine languages, the cultivated polymath, who combined classical learning with Christian piety, a follower of the ideal established by Erasmus. His real contribution to jurisprudence, however, I have yet to mention. This was his Disquisitionum Magicarum libri sex, a handbook on the law of witchcraft, dealing in sophisticated detail with the detection, torture and execution of the miscreant women who were its practitioners. First published in 1599-1600, this major work of Renaissance legal scholarship went through edition after edition throughout the 17 th and 
into the second half of the 18th century. It is a truly great legal textbook, illustrating to the full the ripe humanist learning and erudition of its author.

\section{Legal Humanism and legal history}

Legal humanism in the Renaissance and now - to the legal historian the question has no meaning. Within the field of legal history, legal humanism has a very precise technical significance. It applies to the school, active in the 16th century, particularly in France, which applied historical and philological methods to understanding the sources of Roman law that had survived from antiquity. It is also often taken to apply to the scholars who continued to practice this branch of legal scholarship, particularly in the Netherlands, in the 17th and 18th centuries. At any rate, 1800 is the definitive border. The term legal humanism is never used to refer to any modern approach to Roman law, let alone to modern law.

In the context of legal humanism Kristeller's insistence on keeping the various meanings of humanism absolutely distinct thus seems particularly apt; indeed it has never been called into question:

Many historians, knowing that the term 'humanism' has been traditionally associated with the Renaissance, and seeing that some features of the modern notion of 'humanism' seem to have their counterparts in the thought of that period, have cheerfully applied the term 'humanism' in its vague modern meaning to the Renaissance and to other periods of the past, speaking of Renaissance humanism, medieval humanism, or Christian humanism, in a fashion which defies any definition and seems to have little or nothing left of the basic classicist meaning of Renaissance humanism. This seems to me a bad example of that widespread tendency among historians to impose the terms and labels of our modern time upon the thought of the past. If we want to understand the philosophy of the Renaissance or of any other period, we must try ... to recapture the original meaning in which that period employed certain categories and classifications 
that either have become unfamiliar to us, or have acquired different connotations. In the case of the term 'Humanism' ... it is derived from another similar word, 'humanist', whose origin can be traced back to the Renaissance itself. Humanista in Latin, and its vernacular equivalents in Italian, French, English, and other languages, were terms commonly used in the sixteenth century for the professor or teacher or student of the humanities ... the term humanista ... was in turn derived from an older term, that is, from the 'humanities' or studia humanitatis. This term was apparently used in the general sense of a liberal or literary education by such ancient Roman authors as Cicero and Gellius, and this use was resumed by the Italian scholars of the late fourteenth century. By the first half of the fifteenth century, the studia humanitatis came to stand for a clearly defined cycle of scholarly disciplines, namely grammar, rhetoric, history, poetry and moral philosophy, and the study of each of these subjects was understood to include the reading and interpretation of its standard ancient writers in Latin, and, to a lesser extent, in Greek.

P. 0. Kristeller: Renaissance Thought (New York, 1961)

In the field of legal history Kristeller's warning has always been heeded, for the tendency to seek any connection between modern humanism and that of the Renaissance has been altogether avoided. So even if the details of what legal humanism means to the legal historian are of little interest in the present context, perhaps this very fact is of relevance. For it raises the question of the other disciplines, the humanities proper. Does modern humanism have its roots in Renaissance humanism, that is to say, in the studia humanitatis, the litterae humaniores? Or is the search for the origins of humanism or the humanities in the Renaissance simply an anachronism?

The subject matter of legal humanism, the private law of Rome, is lawyer's law, and is likely to have been studied only by someone who has taken a law degree. The source through which it has been transmitted to us, Justinian's Corpus Iuris Civilis, has probably never passed through the hands of most historians. The most famous names among Roman jurists - Gaius, Ulpian, Paul, Papinian, and Tribonian - probably draw a blank even as to the century 
in which they lived or what they wrote. Yet legal humanism is all about the discovery of this world. In the next few pages, then, I would like to try to sketch, first, the background of Roman law and the sources in which it was transmitted to the medieval and modern worlds, and secondly, to say something about the legal humanists, and how they approached these sources.

\section{Roman law}

Two conceptions are the commonplaces of general knowledge about Roman law. The first is that it was the most brilliant and original achievement of Roman civilization. In literature and the arts the Romans readily acknowledged the Greeks as their masters, whom they could only seek to imitate; but in law they were conscious of their originality. What image does Roman law conjure up to the lay historian? Was Roman law an integral part of the paxRomana, the maintenance of law and order through an even-handed administration of justice, made possible by an alliance of the proconsuls and jurists throughout the far-flung Roman Empire? This image sits rather uneasily with the one criminal trial that sits at the heart of our culture, namely that of an itinerant Jewish teacher tried for sedition in the 30s A.D. in the province of Palestine. The picture of a judge protesting the accused's innocence, but bowing to popular pressure for his execution, is an awkward example of what we are told is a great legal system at work. Yet the latter image perhaps comes closer to the reality. For the Roman jurists had practically no interest in criminal law. They were content to leave the task of rounding up the criminal elements in society to minor officials, who could be relied upon to see to it that social riff-raff would get a sound beating for minor offences, or thrown to the lions or nailed to a cross for more serious infractions. Perhaps a sufficient comment on Roman criminal law is that later ages, accustomed to the use of torture and violent punishments as an integral part of the legal system, referred to the Roman works on this branch of the law as the libri terribiles.

Law and order in the Roman Empire was one thing; Roman law for lawyers quite another. What Roman law is about is property, its use, exchange and inheritance. It is a vast network of rules and principles governing property relations. It addresses itself to the patrimony of private law, the arcana of the professional lawyer, a body 
of professional knowledge, which remains substantially a mystery to the layman. Its subject matter is corporeal and incorporeal property, its mode of acquisition and loss; rights of ownership and possession, of lesser rights of use or usufruct over the property of others, the right to use property vested in another owner; contracts of sale, hire, deposit, loan; degrees of care owed by the hirer or the borrower; the apportionment of the risk of loss; liability for defects in goods sold; formal means of land transfer; compensation for damage to property through negligence; vesting of ownership in dowries and marriage settlements; rights of inheritance at law and under testament; the form and construction of wills, legacies and gifts out of the inheritance; the actions and procedure by which such rights are protected and enforced.

Certain features of Roman private law have to be stressed. First and foremost is the limited number of actors on the legal stage. For us the legal person (corporations aside) is synonymous with the human person, the adults we meet on the street. In Roman law legal persons were very much fewer. The legal person under Roman law was the eldest male in an extended patriarchal family, the paterfamilias. Women, in law as in social reality, played an entirely submissive role. They were by law always subjected to the power of some male. Under early law a woman passed by marriage into the power of her husband; in imperial times, with the advent of so-called "free marriage," this was not so - which meant that she remained subject to the power of the paterfamilias of her original family. If there was no husband and no surviving paterfamilias, she passed into the guardianship of some male relative.

Peculiar to Roman law was that the sons of the family were in a similar condition. Legally they could own no property; anything the filiusfamilias acquired belonged to his father. Indeed the father had the ius vitaenecisque, the right of life or death over his children; restrictions on its exercise were moral and social, but not legal. In a word, the position of women and sons in power was close to that of the slave. The number of actors on the Roman legal stage, then, was very much less than the sum of individual human beings. The actor, the full "legal person," was the head of an extended household, in which women, male descendants, and slaves were subject to his power. The property, which they might handle, vested legally in him. Of course, the law was called upon to evolve various technical devices for getting round the practical difficulties of this situation; the legal complexities and complications to which it gave 
rise form the main subject matter of the "law of persons."

Secondly, we have to remember that the most valuable property apart from land and its buildings was in human beings. Flowing through the heart, arteries and veins of Roman law is the institution of slavery. It is not just that there is an important area of law dealing with their acquisition through purchase or birth and with their manumission; the other areas of law are all impregnated with the complications that arise from human beings as property. Thus liability for physical injury appears in the chapter of law dealing with damage to property; diseases in a slave can give rise to an action for the sale of defective goods. The slave, then, appears on every page of the literature of Roman law.

The Romans themselves saw the beginning of their law in the Twelve Tables, traditionally dated to the mid 5th century B.C. This formed the basis of the old ius civile. Law was very little developed by legislation in Rome. The prime mechanism of development during the Republic was an Edict of the responsible magistrate, the Praetor. Roman law thus developed in two streams, that of strict law, the ius civile, and that of equity, the Praetor's Edict (analogous to the English common law and Equity). By the "classical age" of Roman law, the 2nd and 3rd centuries A.D., these two sources had been codified. (Once again the periodisation is unfamiliar, for the classical period of Roman law falls two centuries after that of Roman literature.) The ius civile had received such a definitive commentary from the jurist Sabinus in the 1 st century A.D. that subsequent jurists wrote on this commentary rather than the ius civile itself. And the Praetor's Edict, which had ceased to be a developing source of law with the decay of the Republican magistracies in the Empire, received a fixed form at the hands of the jurist Julian in the first half of the 2 nd century A.D. These then were the two fundamental sources of Roman private law. But the means whereby they were developed lies at the heart of Roman law. For this was the sphere of the jurist.

A judge in Roman law was a layman, a pillar of society, a man of probity, to whom the parties to a dispute agreed to refer their case; he had no legal training, and on points of law would seek professional advice. Judges therefore played no part in the development of Roman law. Those responsible for the working out of the myriad details of the principles and rules that make up the network of private law were the professional jurists. In the classical period the most famous of these were 
invariably high officials in the imperial bureaucracy. But it was not in their official duties that they developed the law, but in their books. They compiled a huge literature on private law. The typical genres were commentaries on civil law (Ad Sabinum); commentaries on the Praetor's Edict (Ad Edictum); collections of professional opinions on points of law referred to them by clients or lay judges (Quaestiones, Responsa); monographs and tracts on specific areas of law or individual legal topics.

Virtually nothing of this vast literature has come down to us intact. What has survived is due to a compilation made at the command of Byzantine Emperor Justinian in the 6th century A.D., subsequently called the Corpus Iuris Civilis. It is made up of various legal writings primarily of the classical period of Roman law. The heart of the compilation is the Digest. This is a massive conglomeration of juristic writings, reckoned to constitute about one and a half times the size of the Bible, divided into 50 books and 430 titles or subject headings (On marriage, On sale, On legacies, etc.). It is a work of cutting and pasting. Within the titles the text itself is a cento, that is to say, it is made up of a succession of excerpts taken from earlier works of jurisprudence. Dozens of works, of some forty different jurists, were read and excerpted to constitute the new text. These jurists range over almost three hundred years, from the late republic until the third century A.D. In the time of Justinian these writings could therefore be up to six centuries old. To bring the law up to date the compilers were permitted to make alterations and omissions in the text that were known by modern scholars as interpolations.

The second major part of the compilation was called the Codex, (which has nothing to do with a law code, however, but refers literally to the leafed book format as opposed to the classical papyrus roll - which was so much more convenient for a work of reference such as a law book). Again this is divided into books and titles according to subject matter. The Codex is a collection of paragraph-length decisions, decrees and directions of the Emperor, known as imperial constitutions. In this case there is no attempt to weave these individual units into a single whole. Instead, within each title the constitutions are arranged in chronological order. This appears from the date at the end, which records the day, month and the names of the consuls for that year, in what is called its subscription.

Completing the compilation is a short work for law students, the Institutiones, again a cento, but without 
indication of the provenance of the excerpts; and finally the Novellae, new pieces of imperial legislation issued after the promulgation of the original codification. It is in this truncated, re-organised and interpolated form that Roman law was transmitted to the Middle Ages.

When the compilation of Justinian was promulgated at Constantinople in the 6th century the Empire in the West had long ceased to exist. Although introduced into Italy during the short-lived reconquest by Justinian's armies, there is no trace of its subsequent use. In the early Middle Ages there is evidence of the existence of epitomes of the Codex; of the heart of the compilation, the Digest, there is not a whisper. The Carolingian Renaissance, the bottleneck through which so much of Latin literature had to pass to survive, knew nothing of the Digest. It surfaces in Western Europe for the first time in the 11th century. Here begins the renaissance of Roman law.

\section{The School of Legal Humanism}

European legal history, as taught at universities the world over, comes as a severe culture shock to those educated in the Anglo-American legal tradition. For here there are no leading cases, no famous judges defending their independence, no struggles between King and Parliament, no fundamental Bills of Rights, no Magna Carta or Habeas Corpus. Instead, European legal history is played out entirely within the cloisters of the universities, and its participants are not judges or lawgivers, but professors of law. These professors found or belong to a succession of schools: the School of Glossators, the School of Commentators, the School of Humanists, the Elegant School, the Historical School. The law in action or the socio-economic background of the law play no part; the investigation of what the law meant in practice is a recent and daring innovation, seldom practised, and more likely to be carried on by general historians rather than legal historians who have received a formal legal education.

The standard outline of the schools of legal history which will be found in every encyclopedia or manual may be set out as follows:

\section{The Middle Ages}


1. Italy: the School of the Glossators (11th-13th Cent.)

2. Italy: the School of the Commentators (14th-15th Cent.)

II. The Modern Period

1. France: the School of the Humanists (16th Cent.)

2. The Netherlands: the Elegant School (17th-18th Cent.)

\section{The Nineteenth Century}

\section{German - the Historical School}

Legal history thus presents some alarming contrasts to the historical periodisation associated with other elements of the classical tradition. A legal historian who speaks about Roman law in the Renaissance will with certainty be referring to the 16th Century. The founders of legal humanism whom contemporaries already called a triumvirate (Gulielmus Budaeus in France, Andreas Alciatus in Italy, and Ulricus Zasius in Germany) published their first works in the opening two decades of the 16th century. The centre of gravity was the University of Bourges in the mid 16th century, where a whole succession of Famous Names among legal humanists (Baro, Duarenus, Balduinus, Hotmannus, Donellus, Cuiacius) taught at some point. Legal humanism thus has its tentative beginnings a century and a half after what is generally taken to be the first stirrings of humanism in the persons of Petrarch and Boccaccio in the 14th century. To compound the disorientation, the two most famous names in Medieval jurisprudence, Bartolus de Saxoferrato (1314-57) and his pupil Baldus de Ubaldis (1327-1400), were exact contemporaries of Petrarch and Boccaccio. Thus while Europe had entered the Early Renaissance in its art and literature, its jurisprudence was just approaching the summit of the Middle Ages. Again, in the High Middle Ages the centre of European culture is France, with England, Germany, and the Low Countries closely locked into the complex; Italy, by contrast, remains significantly apart. In the world of legal history the Middle Ages is identified with Italy, and in particular with the university of Bologna; in the Renaissance the centre of gravity transfers to France.

"Roman law in the Renaissance," however, has an entirely different connotation for the legal historian as "the renaissance of Roman law." The latter can refer only to the rediscovery and study of the sources of Roman law 
in the 11th-12th centuries. Legal history thus never stood in any need of the "Revolt of the Medievalists" to disassociate the Middle Ages from a period of cultural darkness. In particular, there was never any temptation to discover a "Medieval humanism," to demonstrate that much Latin literature was known and used in the Middle Ages. This was too obvious to require demonstration; the single most significant event in European legal history has from earliest times always been seen as the recovery of the Latin Corpus luris in the 11th century. To be sure, the 16th century did discover some new sources of Roman law; but the master source, the Corpus luris, had been in active use from the 11th century onwards. So from the beginning legal humanism meant a reorientation in the use of existing ancient sources, not the discovery of classical antiquity.

\section{Legal Humanism: the philological and historical method}

The German scholar Ioannes Fridericus Jugler writing in 1755 described legal humanism as follows:

Legal humanism is the study of Roman law joined together in the tightest bond with philosophy (particularly that of the Stoics), antiquities, the Greek and Latin language, the art of textual criticism, Roman history and literature.

Of course, he does not use the expression legal humanism; the term used in earlier periods for legal humanism is jurisprudentia elegantior, or a variant on this form - jurisprudentiacultior, amoenior, politior, and solidior. But the definition remains valid; legal humanism is the application of the philological and historical method to the texts of Roman law, which have survived from antiquity. This methodology has, however, very specific, narrow and technical connotations within the sphere of interpretation of Roman private law.

\section{(1) Textual Criticism}

Humanist philology begins in the 14th century, still well within the age of the manuscript book, and its results can be seen in the contaminated condition of 15th century Latin manuscripts: humanist scholars and 
readers began to change the texts they were reading. They collated manuscripts; they invented the conjecture. First hand acquaintance with the manuscripts gave them practical insight into how corruption occurred during the copying of texts by scribes. The legal texts fared rather differently, and there is no trace of humanist intervention in the manuscripts. Indeed, even the earliest printed editions simply reproduce exactly the manuscript that served as printers' copy, without even an elementary attempt at correction by a humanist editor. These early editions are thus full of the errors that the humanists had long since weeded out of the classical authors. This situation changes definitively at the beginning of the 16th century, when the Latin legal texts were for the first time subjected to the attention (the ravages, on another view) of humanist philology. A new genre of legal literature began to appear: collections of points of textual criticism, which went under the title of Annotationes, Observationes, Emendationes etc. These suggested new readings now found their way into the new editions of the sources, either in the text itself or in marginal annotations. Much more significant was the restoration in these editions of those elements which had been ignored in the Middle Ages, namely the "inscriptions" of the leges of the Digest and the "subscriptions" of the constitutiones of the Code...

\section{(2) Palingenesia of the Roman Jurists}

The Digest of Justinian, as stated, consists of a cento of excerpts from the classical jurists all sown together in a new order. The joins are not invisible, however. Every excerpt notes that at the beginning its provenance in what is called its inscription: the author, the title of the work, the section from which it was taken. At the head of every Digest excerpt we read, for example: Ulpianus libro trigensino primo ad edictum: The jurist Ulpian, Commentary on the Praetor's Edict, Book 31. In the Middle Ages these inscriptions were of no interest. The Digest was treated as a single, unitary, harmonious text. From the twelfth century the inscriptions ceased to be copied in successive manuscripts; the name was retained, but this was often corrupted by error. This is reflected in the earliest printed editions of the 15th and early 16 th centuries.

The restoration of the inscriptions to the Digest text was one of the most fundamental concerns of the humanists. Indeed, it was the key to their whole enterprise. The Digest now ceased to be a uniform code. It broke down into the works of forty individual jurists from different epochs. The humanists put the writings of the individual 
jurists back in their original context. In 1557 Iacobus Labittus published his Index legum omnium quae in Pandectis continentur, which listed all the Digest texts according to the original author and work. The greatest of the humanists, Cuiacius, ceased to write commentaries on the Digest, but instead reconstituted the original works of the Roman jurists on the basis of Labittus' Index, and wrote his commentaries on these "reborn" classical works.

\section{(3) 'Historicisation' of the Codex}

An analogous process can be observed in the case of the other major unit within Justinian's compilation, the Code. Later manuscripts, and the contemporary editions based upon them, lacked the subscription containing the date of the legislation. The restoration of these subscriptions was one of the most basic advances of the new editions that they produced. Now the humanists began to study the imperial decisions and decrees chronologically rather than thematically. They looked at the legislation of an epoch, or a single Roman Emperor, not at decisions (of unknown date) rendered in a particular area of law. The first major work of this character was published by the French humanist, Franciscus Balduinus in 1560, who reconstituted the legislation of the Emperor Justinian from the excerpts scattered throughout the Corpus luris.

\section{(4) Graeca non leguntur: the Discovery of Greek}

One of the salient characteristics of the Renaissance is the recovery of the knowledge of Greek language and literature. This feature would seem to be of little relevance to a subject that was wholly Roman. However, the Roman world was bilingual, and this fact left its trace in the legal sources. The humanists were fascinated by the recovery of the Greek elements in their Corpus luris. The Roman jurists had sometimes affected to quote Greek literature. More important, they had also quoted legal documents (contracts, wills, etc,) sent to them from clients in the Greek-speaking East. The Emperors, too, had rendered their decisions in Greek for the Eastern Empire. All this Greek material had fallen out in the Middle Ages when the knowledge of Greek was tenuous. The humanists set about trying to restore the original text, either by conjecture or by seeking out the early manuscripts that still had traces of the Greek.

More important was the discovery of Byzantine law. Even in the lifetime of Justinian the knowledge of Latin at 
Constantinople was tenuous. Work began immediately on the translation of the Corpus luris into Greek. Their compilatorial character marks subsequent developments in the law of the Byzantine Empire up to its final dissolution in 1453 above all. Like the Corpus luris of Justinian, each new work is an epitome or cento of what had gone before, with additions sown into the texts. This is what rendered the Byzantine legal works of interest to the humanists. Underlying them they could detect, by peering below the encrustation of later ages, the original Latin works of Roman law. By back-translating them into Latin, and comparing the same texts, or texts on the same subject, they found a powerful new tool for criticising the Roman legal texts. Beginning in the 16th century, most of the Byzantine sources that have survived were discovered and edited by the humanists.

\section{(5) Discovery of Classical Works of Roman Law}

The classical period of Roman law is accounted in the 2nd and 3rd centuries A.D. This is when the famous names among the Roman jurists were active, compiling their enormous commentaries on the old civil law of Rome, on the Edict of the Praetor, collections of legal opinions in specific cases, as well as an avalanche of monographs on specific legal themes. Of this vast literature little has survived independently of Justinian, but most of what there is was discovered and edited for the first time in the 16th century. Now the humanists disposed of a dual transmission of Roman law, both direct and through the medium of Justinian's compilation. In some cases the identical text survived in these two forms, so that direct comparison was possible, allowing the humanists to discover precisely the mode of working of Justinian's compilers.

\section{(6) The Detection of Interpolations}

Justinian's compilation was a law in force. Yet for the most part it consisted of materials that had been written 300-400 years previously. Society and its law had not stood still. It was necessary to bring the law up to date. But how was this to be done in a codification that was a patchwork of quotations from ancient writings? The answer was that the out of date portions had to be omitted or altered. Romanists know these changes as interpolations, and the search to find them began in the 16 th century. This above all else is seen as the archetypal activity of the legal humanists. Here they brought their philological and historical skills to bear. 
The humanists sought to detect different styles in the Latin; or they compared directly the texts in the Corpus luris and those which had survived independently; or they noted that a piece of imperial legislation, which they were now in a position to date, had explicitly changed the law on a specific point; hence, they reasoned, a conclusion purporting to be by a jurist of an earlier date exhibiting the new legal position must have been changed to bring it into harmony with the subsequent legislation.

\section{Legal humanism in practice: a case study}

What did all this mean in practice? The historical and philological method was a new way of interpreting the Latin texts of Roman law. A single example will serve to illustrate this method in action. It was usual in a Roman will to nominate one person as heir, and at the same time to name a substitute who should inherit if the first named person, for whatever reason, should not become heir. For various technical reasons it was a common practice to leave an inheritance to a slave, who himself could not own any property, but would acquire it on behalf of his owner, (or rather the owner would acquire it through him). This practice might have given rise to a legal quibble. The clause in the will nominating a substitute would state, "If Titius does not become my heir, then let Sempronius be my heir." But if Titius was a slave, then it could have been argued that, strictly speaking, he did not legally become heir, so that Sempronius should go on to inherit. A strict construction would thus have made it legally impossible to make use of the device of leaving an inheritance to a slave. To get round this difficulty it was a well established rule that the law would construe the term in the will, "if Titius does not become my heir" to mean, "if Titius does not either personally become my heir or alternatively render his master my heir." Legal problem: what if the testator was mistaken about the status of his first name heir, believing that Titius was a free man when he was in fact a slave? Did the testator's error affect the usual construction put on the terms of the will? (For if he had known that Titius was a slave, would he have wanted his estate to go to Titius' owner, or would he rather have given it to the person he named as substitute?) In such a case a simple solution was adopted. The estate was 
divided in two equal shares between the first named heir (i.e. the owner of the first named heir) and the substitute.

A text in the Digest of Justinian [D.28.5.41 (40)] repeats this simple rule:

A testator makes Titius his heir, believing him to be a free man, and nominates Sempronius as substitute in the event that Titius should not become heir. It transpires that Titius is in fact a slave, who at the command of his owner duly accepts the inheritance. In this case it may be said that Sempronius will be admitted to a half share in the inheritance.

This is clearly in full accord with the legal rule set out above. The difficulty is that the text, after discussion of the rule of construction to be put on the word heir, sums up the result again at the end:

Accordingly, in this case the two halves will be divided in such a way that one half will be divided in equal proportions between the owner of the person instituted heir on the one hand, and the substitute on the other.

This would seem to say that a half of the inheritance would be divided between heir and substitute, in other words, one quarter each. Why should this be? And what happened to the other half? For two and a half centuries this knotty legal problem occupied the minds of the greatest names under the legal humanists.

\section{(1) Andreas Alciatus (1492-1550)}

The founder of legal humanism was first in the field with a philological solution: the Latin text was corrupt. Consulting different manuscripts cleared up the difficulty. In an ancient manuscript, as he says, Alciatus found a different reading. The reading of this manuscript was not: "A testator makes Titius his heir," but: "A testator makes Titius his coheir," (coheredem instead of heredem). This reading would mean that Titius first divides half the inheritance with his co-heir; then the half which he receives is further to be divided with the substitute because of the rule about the testator's error. And this nicely explains the quarters at the end of the text. 


\section{(2) Iacobus Cuiacius (1522-90)}

The greatest name among legal humanists had a more historical solution. Research into the actual compilation of Justinian's codification revealed that the compilers were ordered to leave no abbreviations in the text, (which had hitherto been very common in legal manuscripts, given frequent formulaic repetition), which could lead to confusion. All such abbreviations had to be resolved and written out in full. The difficulty in this text arose from a mistaken resolution of a supposed abbreviation. The text says that one half - alter semis - is divided between the heir and substitute. But originally the Roman jurist had written AS DIVIDATUR. An as was a Roman coin, but the word was frequently used metaphorically to signify an inheritance, which was also commonly divided up into twelve parts like the coin. Hence the Roman jurist had said simply that the inheritance should be divided between heir and substitute. But one staff-member of Justinian's commission of compilers had not understood this, and thought he was dealing with an abbreviation A.S. (ancient manuscripts knew no punctuation or spaces between words). This supposed abbreviation he mistakenly resolved as alter semis - giving rise to the false problem of the text.

\section{(3) Emundus Merillius (1579-1624)}

Merillius, a 17th century professor of Bourges, based his solution on Latin linguistic usage. An Alter semi was a kind of loose usage that meant the whole, or both halves as we might say, "let us divide a half between us." To support this theory he cited several of the late grammarians whose commentaries on classical Latin authors had survived; this, then, was how Latin literature could help in the solution of legal problems.

\section{(4) Antonius Faber (1557-1624)}

Faber argued from the original context of the passage. It was not to be understood in the middle of a title of Justinian's compilation on the institution of heirs, where it now stood. The clue lay in the inscription to the passage. This reveals that the passage was drawn from Book 30 of the jurist Julian's casuistic work entitled Digesta. Looking at the other cases dealt with in Book 30 of this work, we find that they are addressed to the case of a slave who was made co-heir. Without necessarily adopting the textual emendation proposed by Alciatus, nevertheless we should hold that this was the real scope 
of the text in its original context. This context has been lost in cutting up the classical juristic works and distributing them in snippets throughout the Digest; reconstituted through their palingenesia, the solution of the difficulty of the present text, with its halves and quarters, lies to hand.

That is just the tip of the iceberg. The most famous names among the humanists all had their say. Connanus said that Alciatus had dreamt up his manuscript reading (a common allegation among humanist scholars); Hotman objected that the abbreviation A.S. for alter semis was not evidenced; and the 17th century Leiden professor Georgius Crusius devoted a whole publication to the question. Indeed, for two and a half centuries different solutions were offered, a slightly different twist here, a new textual emendation there. All this was based on a question of Roman law that did not have the slightest significance for contemporary law.

This, then, is what the studia humanitatis meant in concrete terms to the legal humanists. This, and the thousands upon thousands of other legal points, which crowd on the pages of the enormous body of Latin writings which, constitutes the compilation of Justinian. The knowledge of the ancient world, its history, languages and antiquities, was part of the essential professional training necessary to understand the Latin legal texts. It had nothing to do with creating a good man, a worthy jurist, from the wholesome education provided by Latin and Greek literature. No doubt the legal humanists, being men of their time, did believe that this would be the effect of an education in the humanities - that is, Greek and Latin literature - but that had nothing to do with legal humanism, with the technical requirements of the jurisprudentia elegantior.

To the humanists the Latin text was no longer seen as a seamless web, a unitary codification of law which might have been written yesterday, in which all contradictions had to be explained by legal reasoning, logic, and distinction. A range of new devices could explain apparent divergences:

1. Texts were written in different historical periods. Once the necessary dating had been established, it might emerge that intervening legislation or decisions had changed the law; this explained the different positions adopted by different jurists.

2. Different jurists wrote texts. It was clear, even from the Digest itself, but particularly from the newly 
discovered classical works that the Roman jurists constantly differed in opinion. This explained the apparent contradictions in the Digest; they were not apparent but real.

3. Texts were written in a context other than that in which they were now being cited. This had emerged from the restoration of the Digest inscriptions. Now it could be seen that the jurist was not originally talking about the duty of care of the seller before delivery at all, but that of the hirer during the course of the hire: two quite different contexts, giving rise to different legal results.

4. Texts were corrupt. Different manuscripts had different readings. Symbolically, one of the most common variant readings in the manuscripts was the presence or absence of a negative; on these fact the plaintiff has an action / does not have an action (actionem non habet). Manuscripts were compared; the newly discovered Byzantine sources were consulted to determine what Latin reading their manuscripts must have had. And even where no variant was forthcoming from these sources, the text might still be deemed corrupt and in need of emendation using the new humanist invention of the textual conjecture.

5. Texts were interpolated. The texts had been deliberately altered by Justinian's compilers to bring them up to date many centuries after they were written. Justinian says as much himself in the preface to his codification. With the humanist discovery and editing of classical sources, transmitted independently of Justinian, direct comparison of the same passages could be made. The same might apply to any other text of the Digest; the interpolation of the text might thus explain its reading.

Taken together these devices meant that a new means of interpreting the text had evolved. The text remained, but its meaning had changed. Was the new methodology historical and philological as we are asked to believe? Or were the rules in fact a façade behind which was hidden a new means of interpretation, a means of interpretation which effectively amounted to rewriting the texts. In the great masterwork of legal humanism, the Observationes et Emendationes of Iacobus Cuiacius, published in installments between 1559 and 1595, we see what this new methodology amounted to. The principle of emendation, says Cuiacius, is ratio iuris; the evidence of 
the manuscripts must always bow to this authority. But with this principle Cuiacius had effectively arrogated to himself carte blanche to rewrite the texts as he chose. So in the chapters of the Observationes we see legal cruces now solved by textual emendation: from possumus to non possumus and testatus to intestatus; from et to nec or vel to nec, of dissimilis to similis and simpla to dupla; of probat to negat and substituit to instituit; of filius to filia and emptione to coemptione; of creditor to debitor and debitor to creditor; of patris to matris and ftatris to patris; of tertio to secundo and of secundo to primo. Each of these examples had palaeographical or psychological probability on their side, and were fully within the rules prescribed by philology; each, too, could completely alter the meaning of a closely argued piece of legal logic. It is clear, then, that the philological method was nothing other than a new method of interpreting texts.

\section{How the legal humanists defined legal history}

In 1582 the professor of Roman law at Oxford, the Italian Albericus Gentilis, enunciated the view that legal humanism is bunk. He did not quite express it like this, but, paradoxically perhaps, in the form of six elegant, humanist dialogues, in which the humanist jurists discussed with their opponents the respective merits of the mos Gallicus, the humanist approach, and the mos Italicus, the approach of the practical lawyer. In the introduction to another of his works he was more explicit:

This is the method of legal writing which I have followed, for I find it more worthwhile than that favoured by these inept and ridiculous multi-coloured parrots, who offer absolutely nothing original to the public, apart from their grammaticalisations, their Grecicities, and their textual criticivisms, and all the rest of that stuff, which is all as distant from the profession of a jurist as a parrot itself is from a man.

The sixteenth century lawyer could not have agreed more. The bibliography of 16th century legal printing is massively weighted in one direction: the overwhelming 
importance of Italian medieval jurisprudence. The top sellers are the famous Italian names of the 14th and 15th centuries. From the great printing houses of Lyon, Venice, Frankfurt and Cologne they are reprinted year after year in massive, multi-volume folio sets. Bartolus, Maynus, Tartagni, Decius, Sandeus, De Tudeschis: there is an unbroken continuity from the beginning of significant legal printing, around 1470, until the first decades of the 17th century. An analogous phenomenon is true of the 17th and 18th centuries. The practical lawyers of the Dutch school, Arnoldus Vinnius and Ioannes Voet are printed all over Europe, in one edition after another, in what were clearly huge print-runs (often we find more than one edition with the same imprint and year), and were on every lawyer's shelves. How then did the humanists come to usurp centre stage in the legal history of these centuries? How has the massive weight of endless editions of strictly juristic commentaries on the sources of civil and canon law given way to these rare collections of humanist Annotationes, Emendationes, Observationes? Why is the 16th century identified with legal humanism, and not, say, with the collections of legal opinions of contemporary jurists, the Consilia, or the Decisiones of the great regional and national supreme courts, both of which were printed in far greater numbers and disseminated throughout Europe? Why has the selfpropaganda of the humanists, about an age of renewal, won out over the opinion of Gentilis, with which the vast majority of his contemporaries would have expressed full agreement?

What is the origin of our present-day image of what constitutes legal history? Who decided that professors of law should take centre stage? This periodisation of legal history is of considerable antiquity. It is found in Savigny, considered by legal historians as the founder of their discipline, but the origins of the image pre-date Savigny. A basic work, recommended by Savigny to his students, was the Historia iurisprudentiae Romanae by Ioannes Augustus Bach, first published at Leipzig in 1754. The work is addressed to the history of ancient Roman law, but the final chapter contains a brief outline of its rebirth in the West, "On the recovery of the law of Justinian in the practice and universities of the West." This survey is copied, down to the last detail, from another such history of Roman law - that of Ioannes Salomo Brunquell, published at Jena in 1727. This work, in turn, is equally derivative. The source is the pioneering work of a Neapolitan humanist, Janus Vincentius Gravina, published under the title Origines julis civilis in 1701. An edition of Gravina's work was quickly reprinted at 
Leipzig in 1708, so that it was circulating in the environment in which Brunquell was working.

Of course, there are earlier references to the schola Accursii, or the secta Alciati, but in Gravina we find a whole system of schools set out in rational form. By contrast, for example, the Frenchman Antoine Terrason, writing in 1750, whose starting point is also the recovery of Roman law in the 11th century, devotes individual chapters to each of the national groupings, in which the great names follow one another in chronological order. This is little more than the old tradition of anecdotal biography. In Gravina, however, four clearly defined schools are delineated: the schola Imeriana, Accursiana, Bartolina, and Cuiaciana. Under the schola Cuiaciana the humanist jurists of all nations are gathered together the Italian Alciatus, the Portuguese Goveanus, the Spaniard Augustinus, and above all the French: Baro, Duarenus, Donellus, Hotman, Cujas, Brissonius. The outline ends rather tamely with a mixed bag of names of jurists who "later occupied the place of Cuiacius, drawing on his works as if from the prairies of jurisprudence." It was left to Brunquellus, a quarter of a century later, the age in which the Dutch elegant school was at its height, to discover the next school: that of the "Belgae."

This provides the answer to our question: legal humanism has been placed at the centre of legal history by legal humanists. Gravina, Brunquellus, and Bach were all actively working within the humanist tradition; indeed, such "histories" of law were themselves an integral part of this tradition. To conceive of the history of law as the history of the schools of professors writing about law; to identify the sixteenth century with a school of humanism; this is itself humanist ideology, an ideology to which we are still in thrall. For the line of connection to the modern world is unbroken. The sixth edition of Bach's work was published in 1806; Gravina was translated into French in 1822 . We have reached the age of Savigny, the founder of modern legal history, in whose Juristische Methodenlehre, lectures delivered in the Winter semester 1802/1803, we find the following division of the "Geschichte der Interpretation": a) Glossatoren; b) Kommentatoren; c) Französische Humanisten; d) Holländer; e) Deutsche Schule. But we should not expect a break in this tradition in the nineteenth century. The symbolic start of the new age was the discovery of a complete work of classical Roman law that had survived independently of Justinian. In 1816 Niebuhr discovered in the Capitular library of Verona a palimpsest with works of St. Jerome. Underneath was 
the text of the Roman jurist Gaius, "Gaius noster" as Justinian calls him. The work was edited at Berlin in 1820 , inaugurating the Romanistic side of the programme of the 19th century Historical School.

The echo of the 16th century legal humanists is clear, and it is heard again in the prefaces to modern editions of the pre-classical sources. The times and places that follow go a long way to explaining the modern approach to legal history and the place within it of legal humanism (Fontes iuris Romani Antejustiniani; ed. Baviera):

1. Lex Romana Burgundionun, edited for the first time by Iacobus Cuiacius at Lyon in 1566, then in a revised edition at Paris in $\mathbf{1 5 8 6}$. From the modern period worthy of mention is that of August Friedrich Barkow (Gryphiswald, 1826).

2. Edictum Theodorici Regis, edited for the first time by Petrus Pithoeus at Paris in 1579. From the modern period worthy of mention is that of F. Rhon (Halle, 1816).

3. Pauli Sententiae Receptae, edited for the first time by Petrus Aegidius at Louvain in 1517, and in a much better edition by Cuiacius in 1586. Of later editions of particular use are those of Arndts (Bonn, 1841), Haenel (Leipzig, 1849), and Krueger (Berlin, 1878).

4. Mosaicarum et Romanarum Legum Collatio, edited by Petrus Pithoeus at Paris in 1573. Edited with a critical apparatus by Friedrich Bluhme (Bonn, 1833).

5. Tituli XXVIII ex Corpore Ulpiani, first edited by Ioannes Tills at Paris in $\mathbf{1 5 4 9}$ from a 10th century French manuscript that Cuiacius saw at Paris in 1576, afterwards lost, but rediscovered by Savigny in the Vatican Library. Important editions are those of Backing (Leipzig, 1855), Whale (Bonn, 1856), and Krueger (Berlin, 1878).

Another clue lies in the fact that the manuscript basis of all these pre-Justinianic sources is extremely tenuous; often indeed a text depends upon a unique manuscript. So the work of the legal humanists even had a diplomatic value for the new editions the 19th century scholars were producing. In other words, the humanists were not being studied historically; their work was to be pillaged for the information it might contain on the reading of lost manuscripts. This is true also of the Greek Byzantine sources, which was one of the great pre-occupations of 
the Historical School. The works of the humanists were therefore not so much historical documents as secondary literature. But the humanists also fulfilled another role: they were the giants of the past, icons of the noble and liberal study on which the 19th century scholars too were engaged.

This ideology perhaps emerges nowhere more clearly than in the peroration of Theodor Mommsen's edition of the master source of Roman law, his editio maior of the Digest published at Berlin in 1870. As he lays down his pen after years of unremitting toil, he has cause to doubt the point of it all:

I hope that future scholars will bear witness to the utility of the labour that I have put into editing the Digest. However, I am not unaware of the fact that the true usefulness of the work depends upon the universal condition of these studies, and particularly on the happy conjunction of jurisprudence and Latin letters, which these days has fallen into desuetude, so that those learned in Latin have as little interest in the law as lawyers have knowledge of Latin. There are those who, seeking to encourage my work, think that these studies might revive; nor ought we to despair. The liberal-minded young men who today take up the study of law will see what develops; for it depends on them whether the noble and liberal art of law will endure, or whether it will degenerate into a sordid trade. Roman law, created by the genius of a people born for this very object, burnished by that wonderful journey through twenty centuries and through what were and what are the leading nations of the world, this Roman law, like a noble gold smelted again and again, today shines with a splendour which has not been diminished but rather augmented by age. And although skilful advocates and wise and honest judges may be produced even without training in Roman law, nevertheless in order that the study be rendered worthy of a liberal man, that is, of one who understands that no-one can fully live in the present day if not mindful of times gone by, there will be need of Roman law.

Ancient Rome was built on the institution of slavery, under which human beings were at the legally unrestrained mercy of their owners. Women were permitted no role outside the home (name three famous 
Roman women...), and were effectively under the power of some male. Their husbands might legally discard them without showing cause, while a sexual double morality backed by the lexIulia de adulteriis, insisted on the chastity of the woman and the absolute freedom of the man. (Tolerance of homosexual partnership is an illusion; it amounts to no more than the legal right of the owner to abuse equally the body of his slaves, of whatever age, and of whichever sex.) Power was in the hands of the few who disposed of vast fortunes, while the masses were piled into the rabbit warrens of the insulae of the great cities, dependent on the corn dole. The foremost popular entertainment took the form of the "Games," in which eager crowds could watch human beings being tom apart by wild animals. In short, it was a society of such viciousness that the modern humanist must recoil in speechless horror. But Roman law, the legal system that kept this whole structure in place, has the nobility and purity of burnished gold; this is the image, which we have inherited from the legal humanists.

Douglas J. Osler

Frankfurt am Main

Accueil Surfaces | Table des matières | Recherche $\underline{\text { Surfaces Home Page | Table of Contents | Search }}$

PUM | Livres | Revues | Publications électroniques | Vente et distribution 